Nolia: Model Cooperative Integrated Reading and Compostition (CIRC) untuk Meningkatkan...

\title{
MODEL COOPERATIVE INTEGRATED READING AND COMPOSITION (CIRC) UNTUK MENINGKATKAN HASIL BELAJAR BAHASA INDONESIA MATERI SURAT RESMI KELAS VI SD
}

The Cooperative Integrated Reading Composition (CIRC) Model to Increase The Student's Learning Result in Bahasa Indonesia Material Formal Letter Discussion in The Sixth Grade of Elementary School

Nolia

SD Negeri 5 Manggar

Jalan Tanjung Mudong, Padang, Manggar, Kepulauan Bangka Belitung, Indonesia nolia!@yahoo.co.id

Naskah masuk: 4 Maret 2021, disetujui: 18 Juni 2021, revisi akhir: 22 Juni 2021

\begin{abstract}
Abstrak
Kemampuan peserta didik dalam materi surat resmi sangat rendah sehingga perlu suatu model pembelajaran yang sesuai untuk mengingkatkan kemampuan tersebut. Penelitian ini bertujuan untuk meningkatkan hasil belajar Bahasa Indonesia materi surat resmi dengan model Cooperative Integrated Reading and Composition (CIRC) pada peserta didik kelas VI semester 2 SD Negeri 5 Manggar. Metode yang digunakan pada penelitian ini adalah penelitian tindakan kelas dengan metode analisis data kuantitatif dan deskriptif. Hasil analisis data kuntitatif, yaitu ketuntasan peserta didik secara klasikal pada kegiatan prasiklus $25 \%$, siklus $141,7 \%$, dan siklus $291,7 \%$. Sedangkan analisis deskriptif terdapat peningkatan aktivitas positif peserta didik, yaitu bersemangat dan aktif mengikuti proses pembelajaran pada prasiklus 33,3\%, siklus $175 \%$, dan siklus $2100 \%$. Senang bertanya kepada guru atupun teman tentang materi yang sedang dipelajari pada prasiklus 25\%, siklus $158,3 \%$, dan siklus $283,3 \%$. Menanggapi pertanyaan guru dengan baik pada prasiklus 25\%, siklus $150 \%$, dan siklus $291,7 \%$.
\end{abstract}

Kata kunci : model CIRC, hasil belajar, surat resmi, penelitian tindakan kelas

\begin{abstract}
Student's competency in writing formal letter were very low, so it's necessary to create a learning model that it able to increase the competency. The research aim to increase the learning result in Bahasa Indonesia subject on formal letter material by using cooperative integrated reading and composition to sixt grade students of SD Negeri 5 Manggar in second semester academic year. The action research is choosen as a research method by quantitative and descriptive data analysis Through quantitative analysis result shown students clasical passing grade in pra cycle is $25 \%$ then in the first cycle is $41.7 \%$ and in the second cycle $91.7 \%$. In the other hand, the result of descriptive analysis showed that there were some positive achievements in students activities such as the level of curiousity and their involvement in learning process. The achievement can be showen by the improvement of precentage in every cycle like $33.3 \%$ in pra cycle, $75 \%$ in first cycle and $100 \%$ in second cycle. The study also impact the increasing of student's asking behavior, in pra cycle $25 \%$, first cycle $58.3 \%$ and second cycle $83.3 \%$. The students response to the teacher's questions increase from $25 \%$ in pra cycle to $50 \%$ in first cycle and $91.7 \%$ in the second cycle.
\end{abstract}

Keywords: CIRC Model, learning result, formal letter, action research 
Nolia: Model Cooperative Integrated Reading and Compostition (CIRC) untuk Meningkatkan...

\section{PENDAHULUAN}

Bahasa adalah satu alat komunikasi. Melalui bahasa, manusia dapat saling berkomunikasi, berbagi pengalaman, belajar dari yang lain, dan meningkatkan kemampuan intelektual. Oleh karena itu, belajar bahasa pada hakikatnya adalah belajar komunikasi. Pembelajaran diarahkan untuk meningkatkan kemampuan pembelajaran dalam berkomunikasi, baik lisan maupun tertulis. Hal ini sesuai dengan pendapat Resmini dkk (2006:49) yang mengemukakan bahwa belajar bahasa Indonesia dapat diartikan sebagai sebuah pembelajaran untuk meningkatkan kemampuan peserta didik dalam komunikasi dengan bahasa baik lisan maupun tulis. Bahasa Indonesia merupakan salah satu mata pelajaran di SD, karena bahasa ini mempunyai kedudukan dan fungsi yang sangat penting bagi kehidupan sehari-hari. Tujuan pembelajaran bahasa Indonesia sebagaimana dinyatakan oleh Akhadiah dkk. (1991:1) adalah agar peserta didik "memiliki kemampuan berbahasa Indonesia yang baik dan benar serta dapat menghayati bahasa dan sastra Indonesia sesuai dengan situasi dan tujuan berbahasa serta tingkat pengalaman peserta didik sekolah dasar". Dari penjelasan Akhadiah tersebut, tujuan pembelajaran bahasa Indonesia dapat dirumuskan menjadi empat bagian, yaitu lulusan SD diharapkan mampu menggunakan bahasa Indonesia secara baik dan benar, lulusan SD diharapkan dapat menghayati bahasa dan sastra Indonesia, penggunaan bahasa harus sesuai dengan situasi dan tujuan berbahasa, pengajaran disesuaikan dengan tingkat pengalaman peserta didik SD. Dari tujuan tersebut jelas tergambar bahwa fungsi pengajaran bahasa Indonesia di SD adalah sebagai wadah untuk mengembangakan kemampuan peserta didik dalam menggunakan bahasa sesuai dengan fungsi bahasa itu, terutama sebagai alat komunikasi. Pembelajaran bahasa Indonesia di SD dapat memberikan kemampuan dasar berbahasa yang diperlukan untuk melanjutkan pendidikan di sekolah menengah maupun untuk menyerap ilmu yang dipelajari. Selain itu, pembelajaran bahasa Indonesia juga dapat membentuk sikap berbahasa yang positif serta memberikan dasar untuk menikmati dan menghargai sastra Indonesia. Dalam pembelajaran bahasa Indonesia perlu diperhatikan pelestarian dan pengembangan nilai-nilai luhur bangsa, serta pembinaan rasa persatuan nasional.

Di sekolah dasar negeri 5 Manggar telah dilakukan usaha untuk menumbuhkan kecintaan peserta didik terhadap pelajaran bahasa Indonesia seperti tersedianya pojok baca di setiap kelas dan kegiatan literasi yang dilakukan setiap 15 menit sebelum memulai pelajaran. Namun demikian, masih terdapat kendala-kendala yang sangat mengganggu pembelajaran di kelas yang dilakukan peserta didik, seperti tidak percaya diri untuk menjawab pertanyaan secara lisan, gagal memahami petunjuk pengerjaan soal, sulit dalam membuat kalimat, kurang tepat dalam menempatkan huruf kapital, dan kurang paham dalam menggunakan tanda baca. Bahkan, ada beberapa peserta didik yang tidak lancar membaca.

Gangguan di dalam kelas membuat guru mengalami kendala dalam proses pembelajaran yang sudah direncanakan sebelumnya. Hal ini terjadi karena kekurangan guru itu sendiri dalam memahami karakteristik anak, jarang melaksanakan pembelajaran berkelompok, tidak menggunakan alat peraga yang menyenangkan bahkan tidak menggunakan metode atau strategi yang sesuai dengan tujuan pembelajaran yang ingin dicapai.

Pada era modern ini, perspektif mengajar yang hanya sebatas menyampaikan ilmu pengetahuan itu dianggap sudah tidak sesuai lagi dengan keadaan. Alasan inilah yang kemudian menuntut perlu terjadinya perubahan paradigma mengajar. Dari mengajar hanya sebatas menyampaikan materi pelajaran, menjadi mengajar sebagai proses mengatur lingkungan. Halhal yang menjadi permasalahan di kelas 6 khususnya pelajaran bahasa Indonesia pada kompetensi dasar menulis surat resmi dengan memperhatikan pilihan kata sesuai dengan orang yang dituju perlu diatasi dengan model pembelajaran yang sesuai, yaitu model cooperative integrated reading and composition (CIRC) supaya hasil 
Nolia: Model Cooperative Integrated Reading and Compostition (CIRC) untuk Meningkatkan...

belajar peserta didik dapat meningkat, khususnya pada materi surat resmi.

Untuk mengukur keberhasilan, proses pembelajaran dibagi atas beberapa tingkatan taraf sebagai berikut.

1. Istimewa/maksimal, apabila seluruh bahan pelajaran dapat dikuasai oleh siswa.

2. Baik sekali/optimal, apabila sebagian besar bahan pelajaran dapat dikuasai 76\%-99\%.

3. Baik/minimal, apabila bahan pelajaran hanya dikuasai 60\%-75\%.

4. Kurang, apabila bahan pelajaran yang dikuasai kurang dari 60\%. (Djamarah, 2006: 107).

Hasil belajar adalah suatu pencapaian yang diperoleh oleh siswa dalam proses pembelajaran yang dituangkan dengan angka maupun dalam pengaplikasian pada kehidupan sehari-hari atas ilmu yang didapat. Hasil belajar yang tinggi atau rendah menunjukkan keberhasilan guru dalam menyampaikan materi pelajaran dalam proses pembelajaran. Ketuntasan belajar peserta didik secara individu berdasarkan Kriteria Ketuntasan Minimal (KKM) mata pelajaran bahasa Indonesia kelas 6, yaitu 76. Adapun ketuntasan secara klasikal apabila terdapat $75 \%$ peserta didik mencapai KKM mata pelajaran tersebut, sebagaimana tertuang pada kurikum SD Negeri 5 Manggar.

Penilaian hasil belajar pada hakikatnya merupakan suatu kegiatan untuk mengukur perubahan prilaku yang telah terjadi pada diri peserta didik. Pada umumnya, hasil belajar akan memberikan pengaruh dalam dua bentuk, yaitu peserta didik akan mempunyai perspektif terhadap kekuatan dan kelemahannya atas prilaku yang diinginkan dan mereka mendapatkan bahwa prilaku yang diinginkan itu telah meningkat baik setahap maupun dua tahap sehingga timbul lagi kesenjangan antara penampilan prilaku yang sekarang dengan yang diinginkan.

Penilaian hasil bertujuan untuk mengetahui hasil belajar atau pembentukan kompetensi peserta didik. Standar nasional pendidikan mengungkapkan bahwa penilaian hasil belajar oleh pendidik dilakukan secara berkesinambungan untuk memantau proses, kemajuan, dan perbaikan hasil dalam bentuk penilaian harian, penilaian tengah semester, penilaian akhir semester, dan penilaian kenaikan kelas.

Hasil belajar pada satu sisi adalah berkat tindakan guru, suatu pencapaian tujuan pembelajaran. Di sisi lain, merupakan peningkatan mental siswa. Hasil belajar dapat dibedakan menjadi dampak pengajaran dan dampak pengiring. Kedua dampak tersebut sangat berguna bagi guru dan siswa. Dampak pengajaran adalah hasil yang dapat diukur, seperti tertuang dalam angka rapot, sedangkan dampak pengiring adalah terapan pengetahuan dan kemampuan di bidang lain, suatu transfer belajar (Dimyati dan Mudjiono, 2006: 4).

Model pembelajaran cooperative integrated reading and composition (CIRC) adalah sebuah model pembelajaran yang sengaja dirancang untuk mengembangkan kemampuan membaca, menulis, dan keterampilan-keterampilan bahasa lainnya, baik pada jenjang pendidikan tinggi maupun dasar. Pada tipe model pembelajaran kooperatif yang satu ini, siswa tidak hanya mendapat kesempatan belajar melalui presentasi langsung oleh guru tentang keterampilan membaca dan menulis, tetapi juga teknik menulis sebuah komposisi (naskah). CIRC dikembangkan untuk menyokong pendekatan pembelajaran tradisional pada pelajaran bahasa.

Tujuan penelitian ini adalah untuk meningkatkan hasil belajar bahasa Indonesia dengan model CIRC pada peserta didik kelas VI semester II SD Negeri 5 Manggar pada materi surat resmi. Adapun rumusan masalah yang akan diteliti, yaitu bagimanakah model pembelajaran CIRC dalam meningkatkan hasil belajar bahasa Indonesia di kelas VI semester II SD Negeri 5 Manggar pada materi surat resmi.

Langkah-langkah Model Pembelajaran CIRC (Steven \& Slavin,2008) adalah guru membentuk kelompok heterogen yang beranggotakan empat orang, memberikan wacana/kliping sesuai dengan topik pembelajaran, peserta didik bekerja sama saling membacakan dan menemukan ide pokok dan memberi tanggapan terhadap wacana/kliping dan di tulis pada lembar kertas, dan mempresentasikan/ 
Nolia: Model Cooperative Integrated Reading and Compostition (CIRC) untuk Meningkatkan...

membacakan hasil kelompok lalu guru memberikan penguatan serta membuat kesimpulan bersama peserta didik.

Kemampuan guru dalam memilih model pembelajaran di kelas tidak terlepas dari pengetahuan guru terhadap pemahaman tentang kelebihan dan kekurangan model tersebut. Kelebihan Model CIRC menurut Suprijono (2009:131), yaitu:

1. dalam proses belajar mengajar, siswa dapat memberikan tanggapannya secara bebas;

2. siswa dilatih untuk dapat bekerja sama dan menghargai pendapat orang lain;

3. CIRC amat tepat untuk meningkatkan keterampilan siswa dalam menyelesaikan soal pemecahan masalah;

4. dominasi guru dalam pembelajaran berkurang;

5. siswa termotivasi pada hasil secara teliti, karena bekerja dalam kelompok;

6. para siswa dapat memahami makna soal dan saling mengecek pekerjaannya;

7. membantu siswa yang lemah;

8. meningkatkan hasil belajar khususnya dalam menyelesaikan soal yang berbentuk pemecahan masalah;

9. Pengalaman dan kegiatan belajar anak didik akan selalu relevan dengan tingkat perkembangan anak;

10. seluruh kegiatan belajar lebih bermakna bagi anak didik sehingga hasil belajar anak didik akan dapat bertahan lebih lama; serta

11. membangkitkan motivasi belajar, memperluas wawasan dan aspirasi guru dalam proses pembelajaran.

Kekurangan Cooperative Integrated Reading And Composition menurut Suprijono (2009:132), yaitu:

1. pada saat dilakukan persentasi terjadi kecenderungan hanya siswa pintar yang secara aktif tampil menyampaikan dan gagasan; dan

2. siswa yang pasif akan merasa bosan sebagai tanggung jawab bersama.

\section{METODE PENELITIAN}

Penelitian ini menggunakan metode Penelitian Tindakan Kelas (Classroom Action Research) dengan subjek penelitian siswa kelas 6 SD Negeri 5 Manggar yang berjumlah 12 orang. Penelitian ini dirancang berlangsung selama 3 bulan. Pada bulan pertama (Januari 2020) digunakan untuk persiapan. Yaitu, mempersiapkan pembelajaran dengan membuat Rencana Pelaksanaan Pembelajaran (RPP), membuat media pembelajaran, menyusun instrumen pengamatan dan instrumen tes, menyusun alat evaluasi berupa tes hasil belajar. Dalam hal ini sudah disusun dua rancangan pembelajaran untuk dua siklus. Rencana pembelajaran untuk siklus 1 dilakukan perbaikan berdasarkan hasil refleksi prasiklus. Siklus 2 dilakukan revisi berdasarkan hasil refleksi siklus 1. Penelitian Tindakan kelas ini bertujuan untuk memperbaiki kinerja guru di kelas, sehingga hasil belajar peserta didik semankin meningkat. Wiriaatmaja (2005:75) menyatakan bahwa tujuan dasar Penelitian Tindakan Kelas adalah memperbaiki praktik pembelajaran guru di kelas. Alasan peneliti menggunakan metode Penelitian Tindakan Kelas (PTK) di SD Negeri 5 Manggar adalah untuk (a) memperbaiki proses pembelajaran bahasa Indonesia di kelas sehingga lebih efektif dan bermakna terutama bagi peserta didik sendiri, (b) tidak menuntut waktu khusus artinya tidak mengganggu waktu mengajar guru sebagaimana yang telah disediakan. Guru tetap mengajar sebagaimana biasanya, dan tidak mengganggu komitmennya sebagai pengajar, (c) membantu guru memecahkan masalah yang dihadapi dalam proses belajar mengajar di kelas, (d) menemukan berbagai kelemahan yang telah dilakukan selama ini dalam proses pembelajaran bahasa Indonesia di kelas, (e) mengkaji masalahmasalah situasional dan kontekstual yang dihadapi peserta didik dalam proses pembelajaran bahasa Indonesia.

Prosedur penelitian yang digunakan berbentuk siklus yang mengacu pada modelo Kemmis \& Mc. Taggart (Wiriaatmaja, 2006:66). Alasan dipilih model Kemmis \& Mc. Taggart dalam penelitian ini adalah karena model ini akan mendaur ulang empat kegiatan pokok yang 
Nolia: Model Cooperative Integrated Reading and Compostition (CIRC) untuk Meningkatkan...

berupa perencanaan ( $p l a n)$, pelaksanaan (act), pengamatan (observe), dan refleksi (reflect). Dengan melaksanakan keempat kegiatan pokok ini akan didapat solusi yang berupa perencanaan perbaikan, pelaksanaan tindakan yang telah direncanakan dengan disertai kegiatan observasi, lalu direfleksikan melalui diskusi kembali bersama peneliti sehingga menghasilkan tindakan berikutnya.

Teknik pengumpulan data dalam penelitian ini menggunakan metode tes dan pengamatan. Tes yaitu metode yang digunakan untuk memperoleh data tes hasil belajar kelas VI materi surat resmi. Tes hasil belajar ini dilakukan setelah siklus 1 dan 2 dilaksanakan. KKM Bahasa Indonesia kelas VI SD Negeri 5 Manggar adalah 76, sehingga peserta didik yang mendapatkan nilai di bawah 76 perlu diberikan remedial atau perbaikan.

Pengamatan, yaitu metode yang digunakan untuk memperoleh data tentang keaktifan peserta didik dalam pembelajaran. Pengamatan dilakukan oleh peneliti dan dibantu oleh teman sejawat sebagai observer. Pada pengamatan ini, peneliti dan teman sejawat mengamati keaktifan peserta didik dalam pembelajaran, apakah peserta didik tersebut aktif atau pasif dalam diskusi dan kerja kelompok serta mempresentasikan hasil kerja kelompok.

Dalam melaksanakan Penelitian Tindakan Kelas, pengamatan tidak hanya dilakukan oleh peneliti saja tetapi dibantu oleh teman sejawat sebagai observer dengan pertimbangan bahwa teman sejawat tersebut adalah pengajar di jenjang sebelumnya. Validasi data yang dilakukan meliputi kemampuan berdiskusi dan mengeluarkan pendapat serta tes hasil belajar, sehingga data yang diperoleh diharapkan valid dan dilakukan oleh teman sejawat.

Untuk menganalisis data kuantitatif digunakan analisis deskriptif komparatif, yaitu membandingkan nilai tes kondisi awal (prasiklus), nilai tes setelah siklus 1 dan nilai tes setelah siklus 2 yang digunakan untuk merefleksi kegiatan pada tiap-tiap siklus. Sementara itu, analisis deskriptif digunakan terhadap data hasil pengamatan peserta didik selama proses pembelajaran dengan aspek yang diamati, yaitu partisipasi dalam mengawali pembelajaran, tugas, dan reaksi tugas. Hasil analisis pengamatan keaktifan peserta didik digunakan sebagai bahan masukan untuk merefleksi pembelajaran.

\section{HASIL DAN PEMBAHASAN}

Kegiatan penelitian dilakukan di kelas VI SD Negeri 5 Manggar semester genap tahun pelajaran 2019/2020 dengan jumlah peserta didik sebanyak 12 orang pada mata pelajaran Bahasa Indonesia materi surat resmi.

\subsection{Hasil Penelitian Prasiklus}

Sebelum peneliti menggunakan menggunakan model CIRC, guru hanya menjelaskan materi pelajaran secara lisan dengan menggunakan contoh yang ada di buku teks peserta didik. Setelah itu, peserta didik ditugaskan untuk mengerjakan latihan soal yang ada di buku teks secara individu tanpa memberikan banyak kesempatan kepada peserta didik untuk mengembangkan pengetahuan dan pemahamannya tentang materi yang telah disampaikan oleh guru. Sehingga pada saat pengerjaan soal latihan, peserta didik melakukan aktivitas yang tidak seharusnya terjadi pada saat kegiatan belajar mengajar berlangsung. $\mathrm{Hal}$ ini menyebabkan persentase ketercapaian ketuntasan belajar menjadi rendah. Berikut ini data observasi aktivitas peserta didik.

Tabel 1

Data Observasi Prasiklus

\begin{tabular}{|c|c|c|}
\hline \multirow{3}{*}{ No } & Aktivitas Negari & $\begin{array}{l}\text { Aktivitas } \\
\text { Posittif }\end{array}$ \\
\hline & \multicolumn{2}{|c|}{ Jumlah } \\
\hline & \multicolumn{2}{|c|}{ Persentase } \\
\hline 1. & $\begin{array}{l}\text { Tidak } \\
\text { bersemangat } \\
\text { mengikuti } \\
\text { proses } \\
\text { pembelajaran }\end{array}$ & $\begin{array}{l}\text { Bersemangat } \\
\text { dan aktif } \\
\text { mengikuti } \\
\text { proses } \\
\text { pembelajaran }\end{array}$ \\
\hline & 8 & 4 \\
\hline & $66,67 \%$ & $33,33 \%$ \\
\hline 2. & $\begin{array}{l}\text { Mengobrol } \\
\text { dengan teman } \\
\text { terdekat }\end{array}$ & $\begin{array}{l}\text { Senang } \\
\text { bertanya } \\
\text { kepada guru } \\
\text { atau teman } \\
\text { tentang materi } \\
\text { yang sedang } \\
\text { dipelajari }\end{array}$ \\
\hline
\end{tabular}


Nolia: Model Cooperative Integrated Reading and Compostition (CIRC) untuk Meningkatkan...

\begin{tabular}{rrc}
\hline & \multicolumn{1}{c}{9} & \multicolumn{1}{c}{3} \\
\cline { 2 - 3 } 3. & \multicolumn{1}{c}{$75 \%$} & $25 \%$ \\
Kurang & $\begin{array}{l}\text { menanggapi } \\
\text { pertanyaan } \\
\text { guru }\end{array}$ & $\begin{array}{l}\text { Menanggapi } \\
\text { pertanyaan } \\
\text { guru dengan } \\
\text { baik }\end{array}$ \\
\cline { 2 - 3 } & 9 & 3 \\
\hline $\begin{array}{c}\text { Rata- } \\
\text { rata }\end{array}$ & $72,22 \%$ & $25 \%$ \\
\hline
\end{tabular}

Berdasarkan data observasi aktivitas peserta didik dapat diketahui bahwa $72,22 \%$ peserta didik melakukan aktivitas negatif dengan rincian $66,67 \%$ peserta didik tidak bersemangat mengikuti proses pembelajaran dengan ciri-ciri mata tidak berbinar saat mengikuti pelajaran, tidak segera mengerjakan tugas yang diberikan oleh guru, dan tidak meminta tugas tambahan. $75 \%$ mengobrol dengan teman terdekat. $75 \%$ peserta didik kurang menanggapi pertanyaan guru dalam mengikuti proses pembelajaran. Sebagian kecil peserta didik yaitu $27,78 \%$ yang bersemangat dan aktif, senang bertanya dalam mengikuti proses pembelajaran, dan menanggapi pertanyaan guru dengan baik. Penyebab peserta didik melakukan aktivitas yang tidak seharusnya pada proses pembelajaran dapat disebabkan oleh guru yang tidak melakukan model pembelajaran yang variatif sehingga peserta didik kurang termotivasi untuk aktif mengikuti proses pembelajaran. Besarnya persentase aktivitas negarif peserta didik selama kegiatan pembelajaran sebanding dengan hasil belajar peserta didik yang kurang baik tampak pada tabel berikut:

Tabel 2

Persentase Nilai Prasiklus

\begin{tabular}{cclcc}
\hline No. & Interval & Predikat & Jlh & $\%$ \\
\hline 1. & $0-59$ & Kurang & 5 & 41,67 \\
\hline 2. & $60-75$ & $\begin{array}{l}\text { Baik/ } \\
\text { minimal }\end{array}$ & 4 & 33,33 \\
\hline 3. & $76-99$ & $\begin{array}{l}\text { Baik sekali/ } \\
\text { optimal }\end{array}$ & 2 & 16,67 \\
\hline 4. & 100 & $\begin{array}{l}\text { Istimewa/ } \\
\text { maksimal }\end{array}$ & 1 & 8,33 \\
\hline Tidak Tuntas & 9 & 75 \\
\hline Tuntas & 3 & 25 \\
\hline Jumlah & 12 & 100 \\
\hline
\end{tabular}

Dari persentase nilai prasiklus, hanya 3 peserta didik yang mencapai nilai KKM sebesar 76 , yaitu $25 \%$ peserta didik yang tuntas belajar, sedangkan $75 \%$ siswa tidak tuntas belajar.

Berdasarkan data di atas, penulis dengan teman sejawat mengadakan refleksi dan disepakati untuk menerapkan model CIRC dalam pelajaran bahasa Indonesia pada kompetensi dasar menulis surat resmi dengan memperhatikan pilihan kata sesuai dengan orang yang dituju.

Peneliti berharap dengan diterapkannya model CIRC pada materi surat resmi, peserta didik dapat mengembangkan kemampuan membaca surat resmi sehingga dapat menumbuhkan pemahaman tentang penggunaan tanda baca, struktur kalimat, kalimat efektif, dan sistematika surat resmi. Selain itu peserta didik dapat mengembangangkan kemampuan menulis surat resmi sesuai dengan pemahaman yang didapat.

\subsection{Hasil Penelitian Siklus I}

Pelaksanaan siklus 1 direncanakan bersamaan dengan mulainya materi pada kompetensi dasar 4.2 Menulis surat resmi dengan memperhatikan pilihan kata sesuai dengan orang yang dituju. Rencana yang dilakukan peneliti untuk siklus 1, yaitu (a) memperbaiki RPP (Rencana Pelaksanaan Pembelajaran) pada prasiklus; (b) metode ceramah atau penjelasan secara lisan diganti dengan model CIRC; (c) membuat slide presentasi untuk menampilkan contohcontoh kalimat efektif; (d) memberikan penguatan secara lisan; dan (e) membukukan hasil diskusi kelompok pada akhir proses pembelajaran. Setelah dilakukan kegiatan pembelajaran sebanyak tiga kali pertemuan dengan kegiatan pembelajaran tanya jawab tentang huruf kapital, tanda baca dan penyingkatan gelar, struktur kalimat,dan kalimat efektif. 
Nolia: Model Cooperative Integrated Reading and Compostition (CIRC) untuk Meningkatkan...

Hasil evaluasi belajar pada penelitian siklus 1 seperti pada diagram berikut.

Tabel 3

Perbandingan Hasil Belajar Prasiklus dengan Siklus 1

\begin{tabular}{|c|c|c|}
\hline \multirow{3}{*}{$\begin{array}{l}\text { Interval } \\
\text { Predikat }\end{array}$} & Prasiklus & Siklus 1 \\
\hline & \multicolumn{2}{|c|}{ Jumlah } \\
\hline & \multicolumn{2}{|c|}{ Persentase } \\
\hline $0-59$ & 5 & 3 \\
\hline Kurang & $41,67 \%$ & $25 \%$ \\
\hline $60-75$ & 4 & 4 \\
\hline $\begin{array}{l}\text { Baik/ } \\
\text { minimal }\end{array}$ & $33,33 \%$ & $33,33 \%$ \\
\hline 76-99 & 2 & 2 \\
\hline $\begin{array}{l}\text { Baik } \\
\text { sekali/ } \\
\text { optimal }\end{array}$ & $16,67 \%$ & $16,67 \%$ \\
\hline 100 & 1 & 3 \\
\hline $\begin{array}{l}\text { Istimewa/ } \\
\text { maksimal }\end{array}$ & $8,33 \%$ & $25 \%$ \\
\hline Tidak & 9 & 7 \\
\hline $\begin{array}{l}\text { Tuntas } \\
(0-75)\end{array}$ & $25 \%$ & $41,67 \%$ \\
\hline Tuntas & 3 & 5 \\
\hline $\begin{array}{l}(76- \\
100)\end{array}$ & $25 \%$ & $41,67 \%$ \\
\hline
\end{tabular}

Berdasarkan tabel di atas, terdapat peningkatan ketuntasan belajar secara klasikal pada siklus 1 sebanyak $41,47 \%$. Selain hasil belajar yang mulai mengalami peningkatan, aktivitas positif peserta didik selama kegiatan pembelajaran juga ikut meningkat berdasarkan hasil observasi berikut.

\section{Tabel 4}

Perbandingan Hasil Observasi Prasiklus terhadap Siklus 1

\begin{tabular}{|c|c|c|c|c|}
\hline \multirow{4}{*}{$\begin{array}{l}N \\
0\end{array}$} & \multicolumn{2}{|c|}{ Aktivitas Negarif } & \multicolumn{2}{|c|}{ Aktivitas Posittif } \\
\hline & \multicolumn{4}{|c|}{ Jumlah } \\
\hline & \multicolumn{4}{|c|}{ Persentase } \\
\hline & Prasiklu & Siklus & Prasiklu & Siklus \\
\hline & $\mathrm{s}$ & 1 & $\mathrm{~s}$ & 1 \\
\hline \multirow[t]{3}{*}{1.} & \multicolumn{2}{|c|}{$\begin{array}{l}\text { Tidak } \\
\text { bersemangat } \\
\text { mengikuti proses } \\
\text { pembelajaran }\end{array}$} & \multicolumn{2}{|c|}{$\begin{array}{l}\text { Bersemangat } \\
\text { dan aktif } \\
\text { mengikuti proses } \\
\text { pembelajaran }\end{array}$} \\
\hline & 8 & 3 & 4 & 9 \\
\hline & $\begin{array}{c}66,67 \\
\%\end{array}$ & $25 \%$ & $\begin{array}{c}33,33 \\
\%\end{array}$ & $75 \%$ \\
\hline
\end{tabular}

\begin{tabular}{cccc}
\hline 2. $\begin{array}{l}\text { Mengobrol } \\
\text { dengan } \\
\text { terdekat }\end{array}$ & \multicolumn{2}{l}{$\begin{array}{l}\text { Senang bertanya } \\
\text { kepada } \\
\text { atau } \\
\text { tentang } \\
\text { yang } \\
\text { dipelajari }\end{array}$} & $\begin{array}{r}\text { guru } \\
\text { teman } \\
\text { materi } \\
\text { sedang }\end{array}$ \\
\hline 9 & 5 & 3 & 7 \\
\hline $75 \%$ & 41,67 & $25 \%$ & 58,33 \\
& $\%$ & & $\%$ \\
\hline 3. & $\begin{array}{l}\text { Kurang } \\
\text { menanggapi } \\
\text { pertanyaan guru }\end{array}$ & $\begin{array}{l}\text { Menanggapi } \\
\text { pertanyaan guru } \\
\text { dengan baik }\end{array}$ \\
\hline 9 & 6 & 3 & 6 \\
\hline $75 \%$ & $50 \%$ & $25 \%$ & $50 \%$ \\
\hline
\end{tabular}

Hasil observasi pada siklus 1 , peneliti berdiskusi dengan teman sejawat dan diperolehlah beberapa hasil refleksi sebagai berikut (a) secara umum peserta didik lebih bersemangat dan aktif untuk mengikuti kegiatan pembelajaran dengan model CIRC hal ini terpantau oleh pengamat $75 \%$ peserta didik yang menunjukkan ciri-ciri mata berbinar saat mengikuti pelajaran, segera mengerjakan tugas yang diberikan guru, dan meminta tugas tambahan. Peserta didik dapat saling bekerja sama karena belajar secara berkelompok dan peneliti menggunakan peralatan multimedia untuk mendukung kegiatan pembelajaran, tidak terfokus hanya pada buku teks yang selalu digunakan sebagai satu-satunya sumber bacaan peserta didik; (b) terdapat peningkatan jumlah peserta didik yang bertanya kepada temannya ataupun kepada guru daripada mengobrol dengan teman terdekat, karena peneliti menggunakan LKPD (Lembar Kegiatan Peserta Didik) sebagai acuan peserta didik untuk berdiskusi; (c) peserta didik yang menanggapi pertanyaan guru meningkat pada kegiatan tanya jawab karena peneliti dapat memfokuskan perhatian peserta didik dengan tampilan materi yang akan dipelajari pada slide presentasi; (d) ada kegiatan presentasi hasil diskusi kelompok, hanya satu peserta didik yang berani berbicara di depan kelas sementara anggota yang lain kurang merespons pertanyaan anggota kelompok lain yang bertanya. Padahal, kegiatan ini dapat melatih keterampilan berbicara peserta didik. Hal ini karena sebagian peserta didik kurang 
Nolia: Model Cooperative Integrated Reading and Compostition (CIRC) untuk Meningkatkan...

percaya diri saat diperhatikan oleh peneliti maupun teman sejawat yang ada di dalam kelas saat pembelajaran berlangsung.

Penulis menyimpulkan, model CIRC yang digunakan pada siklus 1 dapat meningkatkan hasil belajar peserta didik walaupun secara klasikal belum tuntas karena peserta didik yang tuntas belum mencapai $75 \%$. Oleh karena itu, penelitian tindakan kelas ini akan dilanjutkan dengan siklus 2 dengan menggunakan Model CIRC dan Model Window Shopping untuk menganti kegiatan presentasi di depan kelas serta menukar anggota kelompok pada saat berdiskusi.

\subsection{Hasil Penelitian Siklus II}

Rencana yang dilakukan peneliti untuk siklus 2 yaitu (a) memperbaiki Rencana Pelaksanaan Pembelajaran (RPP) pada siklus (b) Model CIRC digabungkan dengan Model Window Shooping untuk mengganti kegiatan presentasi; (c) menyiapkan slide presentasi untuk pembelajaran; (d) memberikan umpan balik dan penguatan dalam bentuk lisan terhadap hasil kerja peserta didik; (e) memajang hasil diskusi kelompok peserta didik pada dinding kelas.

Kegiatan belajar pada siklus 2 dilakukan sebanyak tiga kali dengan kegiatan mengenal jenis-jenis surat, menemukan sistematika surat resmi berdasarkan contoh, struktur kalimat dan pilihan kata berdasarkan orang yang dituju. Kegiatan pembelajaran dilakukan secara kelompok, lalu dilanjutkan dengan presentasi hasil diskusi kelompok melalui window shooping ke kelompok lain. Setiap kelompok memberikan penilaian kepada kelompok laian dengan memberikan bintang. Selama melakukan penilaian ke kelompok lain, peserta didik memberikan tanggapan lisan kepada salah satu kelompok lain. Peneliti selalu memberikan pengutan materi setelah peserta didik presentasi dan peneliti memberikan apresiasi berupa pujian kepada peserta didik yang telah berani memberikan tanggapan kepada kelompok lain dan terus membangkitkan motivasi kepada peserta didik yang kurang aktif selama kegiatan pembelajaran berlangsung. Pada kegiatan pembelajaran ketiga, peneliti melakukan penilaian akhir untuk mengetahui perubahan hasil belajar peserta didik.
Tabel 5

Perbandingan Hasil Prasiklus, Siklus 1, dan Siklus 2

\begin{tabular}{|c|c|c|c|}
\hline \multirow{4}{*}{$\begin{array}{l}\text { Interval } \\
\text { Predikat }\end{array}$} & Prasiklu & Siklus 1 & Siklus 2 \\
\hline & $\mathrm{s}$ & & \\
\hline & \multicolumn{3}{|c|}{ Jumlah } \\
\hline & \multicolumn{3}{|c|}{ Persentase } \\
\hline \multirow{2}{*}{$\begin{array}{l}0-59 \\
\text { Kurang }\end{array}$} & 5 & 3 & - \\
\hline & $41,67 \%$ & $25 \%$ & $0 \%$ \\
\hline \multirow{2}{*}{$\begin{array}{l}60-75 \\
\text { Baik/ } \\
\text { minimal } \\
\end{array}$} & 4 & 4 & 1 \\
\hline & $33,33 \%$ & $\begin{array}{c}33,33 \\
\%\end{array}$ & $\begin{array}{c}33,33 \\
\%\end{array}$ \\
\hline \multirow{2}{*}{$\begin{array}{l}76-99 \\
\text { Baik } \\
\text { sekali/ } \\
\text { optimal }\end{array}$} & 2 & 2 & 6 \\
\hline & $16,67 \%$ & $\begin{array}{c}16,67 \\
\%\end{array}$ & $50 \%$ \\
\hline \multirow{2}{*}{$\begin{array}{l}100 \\
\text { Istimewa } \\
\text { / } \\
\text { maksimal }\end{array}$} & 1 & 3 & 5 \\
\hline & $8,33 \%$ & $25 \%$ & $\begin{array}{c}41,67 \\
\%\end{array}$ \\
\hline \multirow{2}{*}{$\begin{array}{c}\text { Tidak } \\
\text { Tuntas } \\
(0-75)\end{array}$} & 9 & 7 & 1 \\
\hline & $25 \%$ & $\begin{array}{c}41,67 \\
\%\end{array}$ & $8,33 \%$ \\
\hline \multirow{2}{*}{$\begin{array}{l}\text { Tuntas } \\
(76- \\
100)\end{array}$} & 3 & 5 & 11 \\
\hline & $25 \%$ & $\begin{array}{c}41,67 \\
\%\end{array}$ & $\begin{array}{c}91,67 \\
\%\end{array}$ \\
\hline
\end{tabular}

Berdasarkan tabel di atas, peserta didik yang tidak tuntas belajar (interval 0-75) sebanyak 1 orang, peserta didik yang tuntas belajar (interval 76-100) sebanyak 11 orang, dan angka ketuntasan peserta didik secara klasikal adalah 91,67 pada siklus 2 yang semula hanya $41,67 \%$ pada siklus 1 .

Peningkatan hasil belajar peserta didik pada siklus 2 sejalan dengan terjadinya perubahan aktivitas peserta didik selama kegiatan pembelajaran. Hal ini tergambar pada tabel berikut:

Tabel 6

Hasil Observasi Aktivitas Belajar Peserta Didik

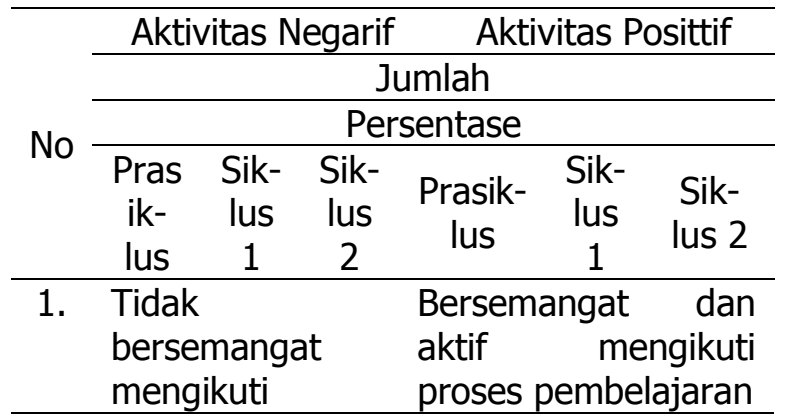


Nolia: Model Cooperative Integrated Reading and Compostition (CIRC) untuk Meningkatkan...

\begin{tabular}{|c|c|c|c|c|c|c|}
\hline & \multicolumn{6}{|c|}{$\begin{array}{l}\text { proses } \\
\text { pembelajaran }\end{array}$} \\
\hline & 8 & 3 & - & 4 & 9 & 12 \\
\hline & 66,6 & 25 & $0 \%$ & 33,33 & 75 & 100 \\
\hline & $7 \%$ & $\%$ & $0 \%$ & $\%$ & $\%$ & $\%$ \\
\hline \multirow[t]{8}{*}{2.} & \multirow{4}{*}{\multicolumn{3}{|c|}{$\begin{array}{l}\text { Mengobrol } \\
\text { dengan te } \\
\text { terdekat }\end{array}$}} & \multirow{4}{*}{\multicolumn{3}{|c|}{$\begin{array}{l}\text { Senang bertanya } \\
\text { kepada guru ata } \\
\text { teman tentans } \\
\text { materi yang sedang } \\
\text { dipelajari }\end{array}$}} \\
\hline & & & & & & \\
\hline & & & & & & \\
\hline & & & & & & \\
\hline & 9 & 5 & 2 & 3 & 7 & 10 \\
\hline & \multirow{3}{*}{$\begin{array}{l}75 \\
\%\end{array}$} & 41, & 16, & \multirow{3}{*}{$25 \%$} & 58 & \multirow{3}{*}{$\begin{array}{c}83,33 \\
\%\end{array}$} \\
\hline & & 67 & 67 & & 33 & \\
\hline & \multirow{3}{*}{\multicolumn{3}{|c|}{$\begin{array}{l}\text { Kurang } \\
\text { menanggapi } \\
\text { pertanyaan guru }\end{array}$}} & \multirow{3}{*}{\multicolumn{2}{|c|}{$\begin{array}{l}\text { Menanggapi } \\
\text { pertanyaan } \\
\text { dengan baik }\end{array}$}} & \\
\hline \multirow{5}{*}{3.} & & & & & & \multirow{2}{*}{ guru } \\
\hline & & & & & & \\
\hline & 9 & 6 & 1 & 3 & 6 & 11 \\
\hline & 75 & 50 & 8,3 & $25 \%$ & 50 & 91,67 \\
\hline & $\%$ & $\%$ & $3 \%$ & & $\%$ & $\%$ \\
\hline
\end{tabular}

Dari hasil observasi, peneliti dan pengamat menemukan hal-hal sebagai berikut, yaitu (a) persentase peserta didik yang tidak bersemangat mengikuti proses pembelajaran menurun menjadi $0 \%$ yang semula pada siklus 1 sebanyak $25 \%$. Semua peserta didik menfokuskan perhatiannya dengan mata yang berbinar saat mengikuti pelajaran, segera mengerjakan tugas yang diberikan oleh guru, dan meminta tugas tambahan, (b) peserta didik yang mengobrol dengan teman menurun menjadi $16,67 \%$ yang semula pada siklus 1 sebanyak 41,67\%, dan (c) peserta didik yang kurang menanggapi pertanyaan guru menurun menjadi $8,33 \%$ yang semula pada siklus 1 sebanyak $50 \%$.

Memperhatikan hasil observasi pada siklus 2, peneliti berdiskusi dengan teman sejawat melakukan refleksi dan diperolehlah hasil (a) semua peserta didik bersemangat dan aktif untuk mengikuti kegiatan pembelajaran dengan model CIRC karena peserta didik belajar secara kelompok dan anggota kelompok selalu berubah-ubah pada setiap kegiatan belajar serta peneliti menggunakan peralatan multimedia untuk menampilkan contoh surat untuk mencapai tujuan pelajaran; (b) peningkatan jumlah peserta didik yang bertanya kepada temannya ataupun kepada guru selaku peneliti daripada mengobrol dengan teman terdekat, karena peneliti menggunakan LKPD dengan materi pelajaran yang saling terkait pada setiap kegiatan belajar; (c) peserta didik yang menanggapi pertanyaan guru meningkat pada kegiatan tanya jawab karena peneliti memfokuskan perhatian peserta didik dengan contoh nyata pada tampilan slide presentasi; (d) kegiatan presentasi hasil diskusi kelompok dilakukan dengan model window shooping sehingga dapat meningkatkan kepercayaan diri peserta didik dalam kemampuan bertanya dan menjawab tanpa merasa terganggu diperhatikan oleh guru selaku peneliti sehingga keterampilan berbicara peserta didik meningkat.

\subsection{Pembahasan}

Pada perencanaan pembelajaran dilakukan perbaikan secara bertahap mulai siklus 1 hingga siklus 2 terhadap kegiatan prasiklus. Pada pembagian alokasi waktu dikegiatan inti saat prasiklus tidak efisien karena guru hanya menggunakan metode ceramah dan penugasan. Pada saat kegiatan siklus I, alokasi waktu yang digunakan mulai efisien tetapi belum maksimal. Belum efisiennya waktu pada siklus 1 terjadi pada saat kegiatan diskusi kelompok dan presentasi. Peserta didik rata-rata malu untuk berbicara di depan kelas untuk presentasi. Pada akhirnya, saat presentasi hasil diskusi kelompok, peserta didik selalu terburu-buru menyelesaikan presentasinya. Pada siklus 2, alokasi waktu yang digunakan sangat efisien karena semua peserta didik terlibat aktif pada kegiatan presentasi dengan metode window shooping.

Penggunaan media berupa LKPD dan slide presentasi yang selalu berubah-ubah pada setiap kali pembelajaran membuat perhatian peserta didik terfokus dari pada menggunakan buku paket saja.

Metode ceramah dan penugasan tidak dapat terlepas pada kegiatan pembelajaran. Namun, jika hanya menggunakan metode ceramah dan penugasan saja, peserta didik akan merasa jenuh dan bosan pada saat belajar. Oleh karena itu, metode ini harus digabungkan dengan metode lain yang lebih menarik seperti model CIRC sehingga peserta didik lebih bersemangat saat mengikuti kegiatan pembelajaran dan dapat 
Nolia: Model Cooperative Integrated Reading and Compostition (CIRC) untuk Meningkatkan...

menguasai semua keterampilan bahasa, yaitu mendengarkan, berbicara, membaca, dan menulis.

Selama pelaksanaan kegiatan pembelajaran pada siklus 1 sampai siklus 2 terdapat peningkatan rata-rata kelas dan persentase ketuntasan peserta didik secara klasikal dibandingakan pada prasiklus. Hal ini dapat tergambar pada diagram berikut.

\section{Tabel 7}

\begin{tabular}{|c|c|c|c|}
\hline \multicolumn{4}{|c|}{$\begin{array}{c}\text { Persentase Ketuntasan Peserta Didik } \\
\text { secara Klasikal }\end{array}$} \\
\hline \multirow[t]{2}{*}{ No. } & \multicolumn{3}{|c|}{ Aspek } \\
\hline & Prasiklus & Siklus 1 & Siklus 2 \\
\hline \multirow{2}{*}{1.} & \multicolumn{3}{|c|}{ Rata-rata kelas } \\
\hline & 51,67 & 65 & 86,67 \\
\hline \multirow[b]{2}{*}{2.} & \multicolumn{3}{|c|}{ Jumlah ketuntasan peserta didik } \\
\hline & 3 & 5 & 11 \\
\hline \multirow[t]{2}{*}{3.} & $\begin{array}{l}\text { Persentase } \\
\text { didik }\end{array}$ & ketuntasan & peserta \\
\hline & $25 \%$ & $41,67 \%$ & $91,67 \%$ \\
\hline
\end{tabular}

Peningkatan rata-rata kelas sejalan dengan peningkatan hasil belajar peserta didik. Hasil belajar peserta didik meningkat disebabkan oleh peserta didik termotivasi pada hasil secara teliti, karena bekerja dalam kelompok. Bekerja sama secara kelompok dapat membantu peserta didik memahami makna soal dan saling mengecek pekerjaannya. Dengan saling mengecek pekerjaannya, peserta didik dapat saling membantu siswa yang lemah dalam belajar. Hal ini sejalan dengan kelebihan model CIRC yang dikemukakan oleh Suprijono (2009:131).

Meningkatnya hasil belajar peserta didik khususnya dalam menyelesaikan soal yag berbentuk pemecahan masalah berbanding lurus dengan perubahan aktivitas positif peserta didik selama kegiatan observasi dilakukan. Perubahan aktivitas positif peserta didik tergambar pada tabel berikut.
Tabel 8

Persentase Observasi Aktivitas Positif Peserta Didik Persiklus

\begin{tabular}{|c|c|c|c|}
\hline \multirow{2}{*}{ No. } & \multicolumn{3}{|c|}{ Aktivitas Positif } \\
\hline & Prasiklus & Siklus 1 & Siklus 2 \\
\hline \multirow[t]{2}{*}{1.} & \multicolumn{3}{|c|}{$\begin{array}{l}\text { Bersemangat dan aktif mengikuti } \\
\text { proses pembelajaran }\end{array}$} \\
\hline & $33,33 \%$ & $75 \%$ & $100 \%$ \\
\hline \multirow[t]{2}{*}{2.} & \multicolumn{3}{|c|}{$\begin{array}{l}\text { Senang bertanya kepada guru atau } \\
\text { teman tentang materi yang sedang } \\
\text { dipelajari }\end{array}$} \\
\hline & $25 \%$ & $58,33 \%$ & $83,33 \%$ \\
\hline \multirow[t]{2}{*}{3.} & \multicolumn{3}{|c|}{$\begin{array}{l}\text { Menanggapi pertanyaan guru } \\
\text { dengan baik }\end{array}$} \\
\hline & $25 \%$ & $50 \%$ & $91,67 \%$ \\
\hline
\end{tabular}

Berdasarkan tabel di atas, aktivitas positif peserta didik meningkat di tiap siklus. Pada siklus 2, 100\% peserta didik bersemangat dan aktif mengikuti proses pembelajaran. Slavin (2015:11) mengatakan bahwa kekuatan model CIRC adalah terciptanya pembelajaran yang bersifat aktif, menyenangkan, mengikat, dan sosial. Keaktifan peserta didik terlihat dari peningkatan persentase senang bertanya kepada guru atau teman tentang materi yang sedang dipelajari mencapai $83,33 \%$ pada siklus 2. Hal ini sesuai dengan keunggulan Model CIRC yang disebutkan oleh Suprijono (2009:131), yaitu siswa termotivasi pada hasil secara teliti, karena bekerja dalam kelompok. Dengan bekerja dalam kelompok sehingga dapat memotivasi peserta didik senang bertanya kepada teman atau guru tentang materi yang dipelajari. Jika peserta didik senang bertanya maka dalam proses belajar mengajar, peserta didik dapat memberikan tanggapan secara bebas sesuai dengan kelebihan Model CIRC yang disebutkan oleh Suprijono (2009:131). Oleh karena itu, langkah-langkah pembelajaran Model CIRC dapat meningkatkan aktivitas positif peserta didik sesuai dengan kelebihan Model CIRC oleh Suprijono (2009:131).

Memperhatikan peningkatan hasil belajar dan aktivitas peserta didik selama pembelajaran menjadi dorongan peneliti untuk melakukan refleksi bersama teman sejawat dengan memeperhatikan ketuntasan peserta didik pada diagram berikut. 
Nolia: Model Cooperative Integrated Reading and Compostition (CIRC) untuk Meningkatkan...

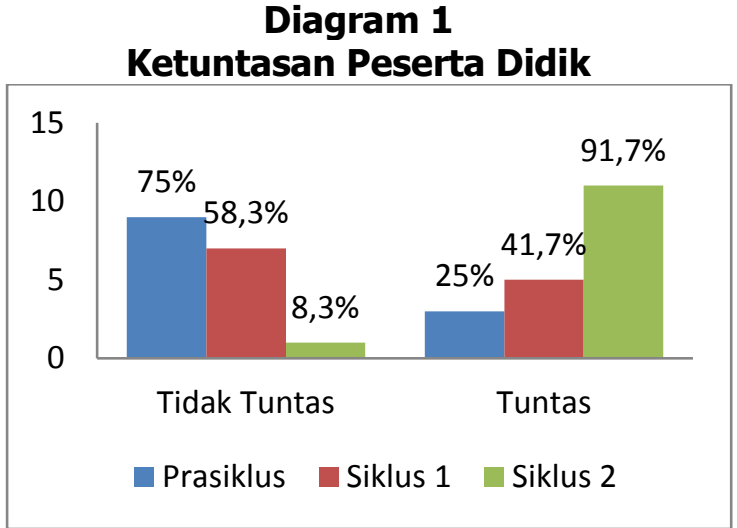

Berdasarkan hasil evaluasi akhir yang tergambar pada grafik di atas terdapat penurunan ketidaktuntasan dan peningkatan ketuntasan peserta didik dari prasiklus sampai siklus 2 . Kriteria Ketuntasan Minimal kelas pada mata pelajaran Bahasa Indonesia adalah 76. Indikator hasil belajar peserta didik yang tuntas adalah peserta didik yang memperoleh predikat baik sekali/optimal dengan rentang 76-99 dan predikat istimewa/maksimal dengan nilai 100 (Djamarah, 2006:107) sebanyak 11 orang dengan persentase ketuntasan secara klasikal $91,7 \%$. Hal ini senada dengan hasil penelitian Achril Zalmansyah (2018:229) bahwa teknik CIRC terbukti dapat meningkatkan kemampuan menulis narasi siswa.

\section{SIMPULAN}

Berdasarkan penelitian yang telah dilakukan, dapat disimpulkan bahwa pemanfaatan model CIRC pada pelajaran Bahasa Indonesia mampu meningkatkan hasil belajar peserta didik. Meningkatnya hasil belajar peserta didik, secara langsung meningkatnya juga persentase ketuntasan belajar secara klasikal. Pemanfaatan model CIRC dikolaborasikan dengan model Window Shooping mampu meningkatkan semangat dan keaktifan peserta didik dalam menerima pelajaran serta melatih keterampilan berbicara. Melihat keberhasilan penerapan model CIRC, guru merasa tertantang untuk lebih inovatif dan kreatif dalam setiap kegiatan pembelajaran.

Berdasarkan hasil penelitian yang telah dilakasanakn, disarankan supaya model pembelajaran CIRC dapat selalu dipakai dalam pembelajaran Bahasa Indonesia karena dapat mengembangkan kemampuan membaca, menulis, dan keterampilanketerampilan berbahasa lainya. Sebelum melaksanakan pembelajaran, guru harus memahami langkah-langah model pembelajaran CIRC serta mempersiapkan segala sesuatu yang menunjang proses pembelajaran seperti: materi ajar, media pembelajaran, dan metode atau model pembelajaran pendukung yang dapat meningkatkan semangat serta keaktifan peserta didik.

\section{DAFTAR PUSTAKA}

Agus, Suprijono. (2009). Cooperative Learning: Teori dan Aplikasi PAIKEM. Yogyakarta: Pustaka Pelajar.

Akhadiah, Sabarti dkk (1991). Pembinaan Kemampuan Menulis Bahasa Indonesia. Jakarta: Erlangga.

A.M. Sardiman. (2004). Interaksi dan Motivasi Belajar Mengajar. Jakarta: Raja Grafindo Persada.

Dimyati dan Mudjiono. (2006). Belajar dan Pembelajaran. Jakarta: PT Rineka Cipta.

Djaali. (2008). Psikologi Pendidikan. Jakarta: Bumi Aksara.

Djamarah, Syaiful Bahri. (2006). Strategi Belajar Mengajar. Jakarta: PT Rineka Cipta.

Fathurrohman, Muhammad. (2015). ModelModel Pembelajaran Inovatif: Alternatif Desain Pembelajaran yang Menyenangkan. Yogjakarta: Ar-Ruzz Media

Novi, Resmini dkk. (2006). Membaca dan Menulis di SD: Teori dan Pengajarannya. Bandung: UPI PRESS.

Rochiati, Wiriaatmadja. (2005). Metode Penelitian Tindakan Kelas. Bandung: Remaja Rosdakarya. 
Nolia: Model Cooperative Integrated Reading and Compostition (CIRC) untuk Meningkatkan...

Rullyanda, Dodi. 2014. "Pengertian, Tujuan dan Ruang Lingkup Pembelajaran Bahasa Indonesi," dalam https://dodirullyandapgsd.blogspot.c om/2014/ 08/pengertian-tujuan-danruang-lingkup 17.html, diakses 24 Maret 2020 pukul 23.03 WIB.

Sabarudin. (2020). Praktis Belajar Best Practice Teori dan Praktik. Yayasan Sahabat Alam Rafflesia.

Slavin, Robert E. (2008). Cooperative Learning Teori, Riset, dan Praktik. Bandung: Nusa Media.

Zalmansyah, Achril. (2018). "Teknik Cooperative Integrated Reading and Composition (CIRC) untuk Meningkatkan Kemampuan Menulis," Jurnal Kajian Bahasa Ranah, Vol 7, No. 2, hlm 229-246. 